\title{
Measurement and modeling of the Saharan dust radiative impact: Overview of the Saharan Dust Experiment (SHADE)
}

\author{
D. Tanré, ${ }^{1}$ J. Haywood ${ }^{2}$ J. Pelon, ${ }^{3}$ J. F. Léon, ${ }^{1}$ B. Chatenet, ${ }^{4}$ P. Formenti, ${ }^{5,6}$ P. Francis, ${ }^{2}$ \\ P. Goloub, ${ }^{1}$ E. J. Highwood, ${ }^{7}$ and G. Myhre ${ }^{8}$
}

Received 2 December 2002; revised 24 February 2003; accepted 26 March 2003; published 6 August 2003.

[1] Aerosols are known to be important in determining Earth's radiative balance. Dust aerosols are of particular interest since, in addition to their scattering and absorbing properties that affect the solar radiation, they also perturb the terrestrial radiation. Recent studies have shown that a significant proportion of mineral dust in the atmosphere may be of anthropogenic origin, and therefore they may have an important role in climate change by exerting a significant radiative forcing. However, the optical and radiative properties of dust are not yet very well-determined, and even the sign of the resulting forcing is still questionable. The Saharan Dust Experiment (SHADE) was designed to better determine the parameters that are relevant for computing the direct radiative effect. Two aircraft combining in situ and remote sensing instruments were coordinated with satellite overpasses and ground-based observations during the experiment, which was based in the Cape Verde area during the period 19-29 September 2000. These in situ and remotely sensed data provide new valuable information on the microphysical, optical properties, and radiative effects of a large mineral dust outbreak. In addition, a global chemical transport model was used for assessing the radiative impact of these events, which are shown to be important on regional and global scales. INDEX TERMS: 0305 Atmospheric Composition and Structure: Aerosols and particles (0345, 4801); 3359 Meteorology and Atmospheric Dynamics: Radiative processes; 3360 Meteorology and Atmospheric Dynamics: Remote sensing; KEYWORDS: Saharan dust, physical and optical properties, dust direct radiative forcing

Citation: Tanré, D., J. Haywood, J. Pelon, J. F. Léon, B. Chatenet, P. Formenti, P. Francis, P. Goloub, E. J. Highwood, and G. Myhre, Measurement and modeling of the Saharan dust radiative impact: Overview of the Saharan Dust Experiment (SHADE), J. Geophys. Res., 108(D18), 8574, doi:10.1029/2002JD003273, 2003.

\section{Introduction}

[2] Atmospheric aerosols are known to impact the climate evolution but they still represent one of the largest uncertainties in climate change studies [Intergovernmental Panel on Climate Change (IPCC), 2001]. Among the different aerosol types, mineral dust is one of the major contributors to Earth's radiative budget. It backscatters to space a significant fraction of the solar radiation because, with the possible exception of sea-salt aerosol, the dust loading in the atmosphere is the most abundant of all aerosol species

\footnotetext{
${ }^{1}$ Laboratoire d'Optique Atmosphérique, Centre National de la Recherche Scientifique, Université des Sciences et Technologies de Lille, Villeneuve d'Ascq, France.

${ }^{2}$ Met Office, Bracknell, UK.

${ }^{3}$ Service d'Aéronomie, Centre National de le Recherche Scientifique, Université Pierre et Marie Curie, Paris, France.

${ }^{4}$ Laboratoire Inter-Universitaire des Systèmes Atmosphériques, Centre National de le Recherche Scientifique, Université Paris 12, Paris, France.

${ }^{5}$ Max Planck Institute for Chemistry, Mainz, Germany.

${ }^{6}$ Now at Centre of Geophysics of Evora, Universidade de Évora, Évora, Portugal.

${ }^{7}$ Department of Meteorology, University of Reading, Reading, UK.

${ }^{8}$ Department of Geophysics, University of Oslo, Oslo, Norway.

[Penner et al., 2001]. It also impacts the terrestrial irradiance and has a similar effect to that of greenhouse gases due to their absorption in the longwave and relatively large size of the dust particles which interact efficiently with terrestrial radiation. Over ocean in cloud-free conditions, the dust perturbation to the solar radiation budget results in a strong local cooling effect which can be as large as $-60 \mathrm{~W} \mathrm{~m}^{-2}$ during important dust outbreaks [Haywood et al., 2001]. Over land, dust may exert either a positive or negative radiative effect depending on the values of the surface albedo and of the aerosol single scattering albedo [e.g., Tegen et al., 1996; Hansen et al., 1997]. Because of this complexity and due to uncertainties in the dust radiative properties, the sign of the resulting effect given by climate models is not yet determined [IPCC, 2001; Ramaswamy et al., 2001].

[3] There is clearly a need for better measuring the dust physical and optical properties within the solar and the terrestrial spectrum [Karyampudi et al., 1999; Sokolik et al., 2001]. Concurrent measurements of the radiances and irradiances together with these physical and optical properties allow testing of radiative transfer codes to ensure that the assumptions made in modeling the radiative properties of the mineral dust are reasonable and provide "radiative closure" where agreement is sought between in situ and 
remote sensing data. Additionally, if consistency is achieved then we have greater confidence in both the in situ and remotely sensed retrievals. Satellite measurements offer a promising opportunity for reducing the uncertainty in estimates of the direct radiative impact due to aerosols. In this regard, the so-called A-Train will be the first space mission to provide a very comprehensive aerosol data set. It will include the Moderate-resolution Imaging Spectroradiometer (MODIS) and Clouds and the Earth Radiant Energy System (CERES) sensors aboard the AQUA platform launched in May 2002, that respectively measure radiances over a large spectral range [King et al., 1992] and the solar and terrestrial reflected irradiances [Wielicki et al., 1996], a Polarization and Directionality of the Earth's Reflectances (POLDER) type instrument aboard the PARASOL satellite [Deschamps et al., 1994], and a backscatter Lidar combined with an IR imager included in the CALIPSO payload [Winker et al., 2002] that will be both launched in the fall 2004. Combining the data should provide a better characterization of the aerosol layers [Kaufman et al., 2003] but requires preliminary studies. The Saharan Dust Experiment (SHADE) was also designed for getting a data set similar to the A-Train one for checking in the case of dust the validity of the aerosol inversion scheme that will be applied to the satellite data for a comprehensive aerosol data set. Once the radiative properties of mineral dust aerosol have been established by in situ and remotely sensed data, they can be used as input or for validation of global circulation models that generate aerosol size distributions using emission models and advect the aerosols with meteorological windfields. This allows computation of the dust radiative impact on a regional and even a global scale. Furthermore, the in situ and remotely sensed data can be used to further validate these model estimates, thereby providing increased confidence that the model estimates are realistic. SHADE was designed to respond to these objectives.

[4] The experiment took place in September 2000 off the coast of west Africa near the Cape Verde Islands. During the experiment, the UK C-130 aircraft flew below, within, and above dust layers for measuring the in situ physical, chemical, and radiative properties and remotely sensed the aerosols using radiation equipment. The French Mystere20 aircraft flew above the aerosol layer and made remote sensing measurements during MODIS daytime overpasses with a combined radiation equipment, the airborne POLDER simulator and the backscatter Lidar LEANDRE. Ground-based sunphotometers were deployed in Sal Island of the Cape Verde archipelago and in M'Bour, $80 \mathrm{~km}$ south of Dakar, Senegal and data were processed as part of Aerosol Robotic Network (AERONET) [Holben et al., 1998].

[5] Section 2 briefly describes the instruments that were deployed and the satellite data that are used in the study. Section 3 presents an overview of the meteorological and dust conditions during the experiment, while section 4 discusses the scientific questions and summarizes the main results.

\section{Instrumentation}

[6] The Met Office C-130 research aircraft was based in Sal Island between the 19th and the 29 September 2000, where it conducted a series of flights over the ocean and over surface-based CIMELs Sun photometer sites in Sal Island and in M'Bour. The French Mystere20 aircraft (M20) was equipped with the backscattering Lidar LEANDRE-1 (CNRS/IPSL) and the POLDER (CNRS/LOA) airborne versions and was also stationed in Sal Island between the 21st and the 29 September. Data from relevant satellite overpasses included the Total Ozone Mapping Spectrometer (TOMS) that was used for planning purposes as it provided daily information on the location of the aerosol plume. The MODIS instrument on the TERRA satellite and the CERES instrument on the TRMM satellite also provided data on the aerosol optical depth, $\tau_{a e r}$, and the aerosol direct radiative effect respectively. Figure 1 gives a schematic diagram of the various measurement platforms operating during SHADE. The description of the airborne instruments is given hereafter. A brief description of the ground-based measurements as well as the MODIS data is provided.

\subsection{C-130 Instrumentation}

[7] The instruments onboard the C-130 were designed and operated by several different international organizations, including the Met Office (UK), Max Planck Institute (Germany), University of Leeds (UK), University of Stockholm (Sweden), and KFA (Germany). The instruments and measurements are fully described by Haywood et al. [2003]. The relevant instrumentation that is used here can be split up into in situ and radiation measurements.

[8] Standard in situ instrumentation included a pressure probe, two temperature probes, and two dew point/relative humidity probes. In situ measurements of the physical, chemical and optical properties of the aerosol were performed. The aerosol size distribution was measured using the PCASP (Passive Cavity Aerosol Spectrometer Probe 100X), and the FFSSP (Fast Forward Scattering Spectrometer Probe). The FFSSP did not operate reliably during the campaign and the data is not used in the analyses presented in subsequent papers. The Small Ice Detector (SID) was also installed. SID was originally designed for measuring ice crystal habits but can used for determining the asphericity of the aerosol particles [Haywood et al., 2003]. The chemical composition was inferred by airborne filter sampling [Formenti et al., 2003]. The particulate absorption of radiation was measured at wavelength $0.567 \mu \mathrm{m}$ with a Radiance Research Particle Soot Absorption Photometer (PSAP). The aerosol scattering was determined at 3 wavelengths $(0.45,0.55,0.70 \mu \mathrm{m})$ with a TSI 3563 nephelometer.

[9] Radiation instruments included upward and downward facing Eppley broadband radiometers (BBRs) fitted with clear and red domes which cover the $0.3-3.0 \mu \mathrm{m}$ and 0.7-3.0 $\mu \mathrm{m}$ spectral regions respectively [e.g., Haywood et al., 2001]. The Scanning Airborne Filter Radiometer (SAFIRE) designed by the Met Office measured radiances in 7 of the 16 bands across the visible and near-infrared region of the spectrum, from $0.55 \mu \mathrm{m}$ up to $2.1 \mu \mathrm{m}$ [Francis et al., 1999]. The Airborne Research Interferometer Evaluation System (ARIES) was used to measure radiances at a high spectral resolution of approximately $0.5 \mathrm{~cm}^{-1}$ [Highwood et al., 2003]. Finally, a short-wave spectrometer (SWS) using two modules operating in the spectral range 


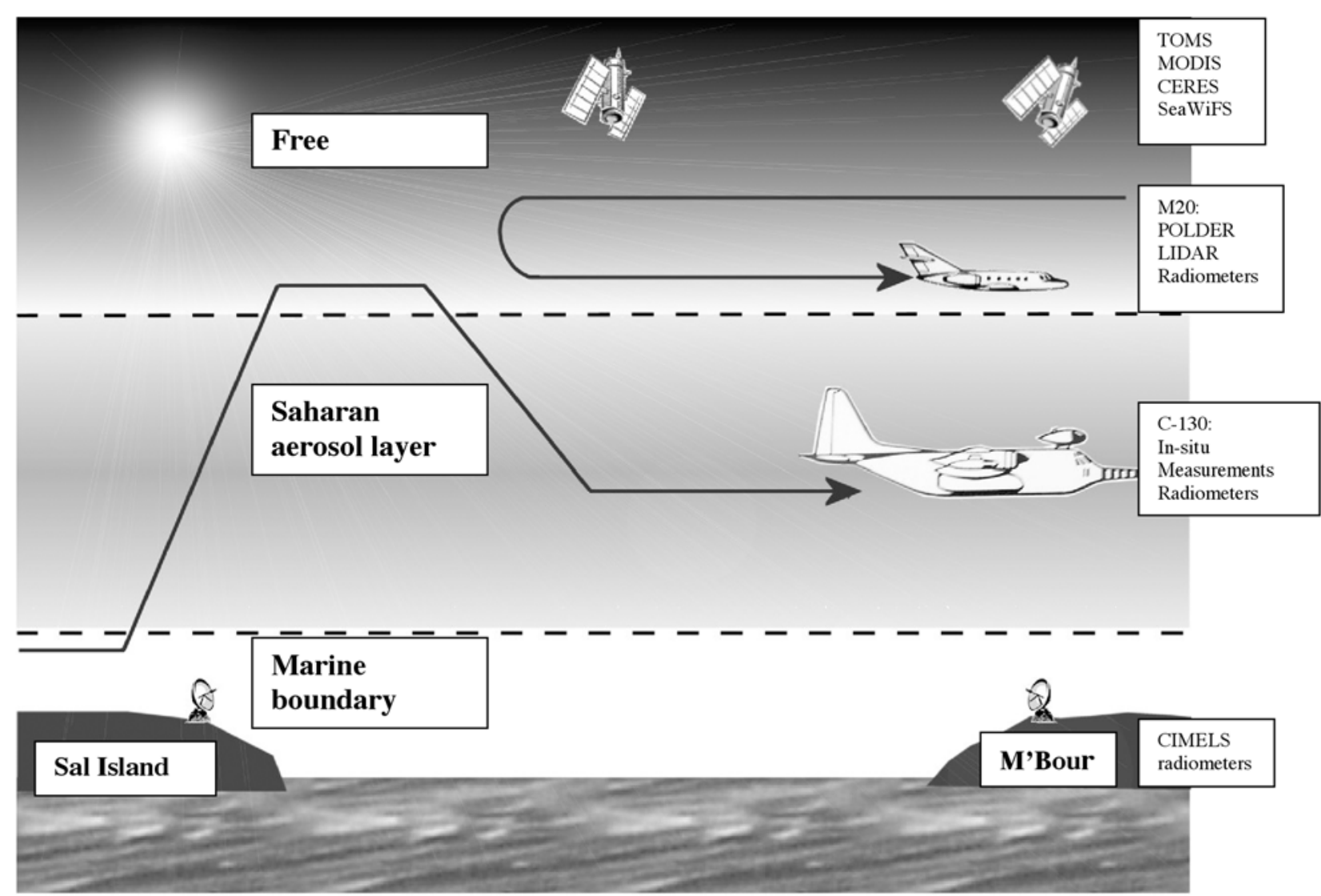

Figure 1. Schematic diagram of the operation of the C-130, and M20 aircrafts between Sal Island and M'Bour. Satellite instruments used in this study include TOMS, MODIS, CERES, and SeaWiFS.

$0.30-0.95 \mu \mathrm{m}$ and $0.95-1.70 \mu \mathrm{m}$ and providing nadir views was installed.

\subsection{M20}

[10] The French Mystere20 aircraft was also equipped with Eppley broadband radiometers with standard in situ sensors for pressure, temperature and humidity. There were two remote sensing instruments onboard, the backscatter Lidar LEANDRE 1 designed at CNRS/IPSL and the airborne version of POLDER designed at CNRS/LOA. The Lidar LEANDRE 1 [Pelon et al., 1990] allows observations of the vertical structure of the aerosol layer by a dual polarization channel at $0.532 \mu \mathrm{m}$ and a second channel operating at $1.064 \mu \mathrm{m}$. The airborne version of POLDER is similar to the instrument that flew on ADEOS-1 platform [Deschamps et al., 1994]). It measures the solar radiation reflected by Earth between 0.440 and $0.865 \mu \mathrm{m}$ including the directional information and also the polarization signatures at 0.665 and $0.865 \mu \mathrm{m}$.

\subsection{AERONET Data}

[11] Two instruments of the Aerosol Robotic Network [Holben et al., 1998] data were operating during the experiment. They were located in Sal Island (N14 ${ }^{\circ} 43^{\prime}$, $\left.\mathrm{W} 22^{\circ} 56^{\prime}\right)$ and in $\mathrm{M}^{\prime}$ Bour $\left(\mathrm{N} 16^{\circ} 43^{\prime}, \mathrm{W} 22^{\circ} 56^{\prime}\right)$. The inversion scheme developed by Dubovik et al. [2002a] was applied to the data, which allows retrieval of aerosol size distributions, refractive index and single scattering albedo in the visible and near infrared. The operational cloud screening [Smirnov et al., 2000] was used. It should be noted that, in some cases, dust plumes are screened since the cloud contamination is based on the temporal variations of the optical thickness. Level 2 products were used which means that post-field calibration was applied and data were quality assured. As expected, the size distribution retrieval indicates that, in terms of aerosol mass, there is one coarse mode with an effective radius around 1.5-2.0 $\mu \mathrm{m}$. Nonsphericity effects can affect the retrieval for submicron aerosol sizes and an alternative inversion scheme [Nakajima et al., 1996] less sensitive to aerosol shape was therefore used.

\subsection{Satellite Data}

[12] To obtain data similar to those of the A-Train, the M20 flights were coordinated to be coincident with the overpass of the MODIS instrument on the TERRA platform. The aerosol parameters that are used by Léon et al. [2003], are the level 2 products over ocean derived at 10-km spatial resolution [Tanré et al., 1997], i.e., the aerosol optical thickness $\left(\tau_{\text {aer }}\right)$ at $0.55 \mu \mathrm{m}$, the small and the large size modes of the aerosol size distribution and the ratio between the modes. Validation of MODIS aerosol products over ocean showed that MODIS $\tau_{\text {aer }}$ are accurate to within $\left( \pm 0.03 \pm 0.05 * \tau_{\text {aer }}\right)$ at wavelengths at $0.66 \mu \mathrm{m}$ and $0.86 \mu \mathrm{m}$ and the effective radius to within $0.1 \mu \mathrm{m}$ [Remer et al., 2002]. In dust aerosol regimes, the retrieved $\tau_{\text {aer }}$ aerosol optical at other wavelengths have greater errors due to nonspherical effects and additionally aerosol size is under- 

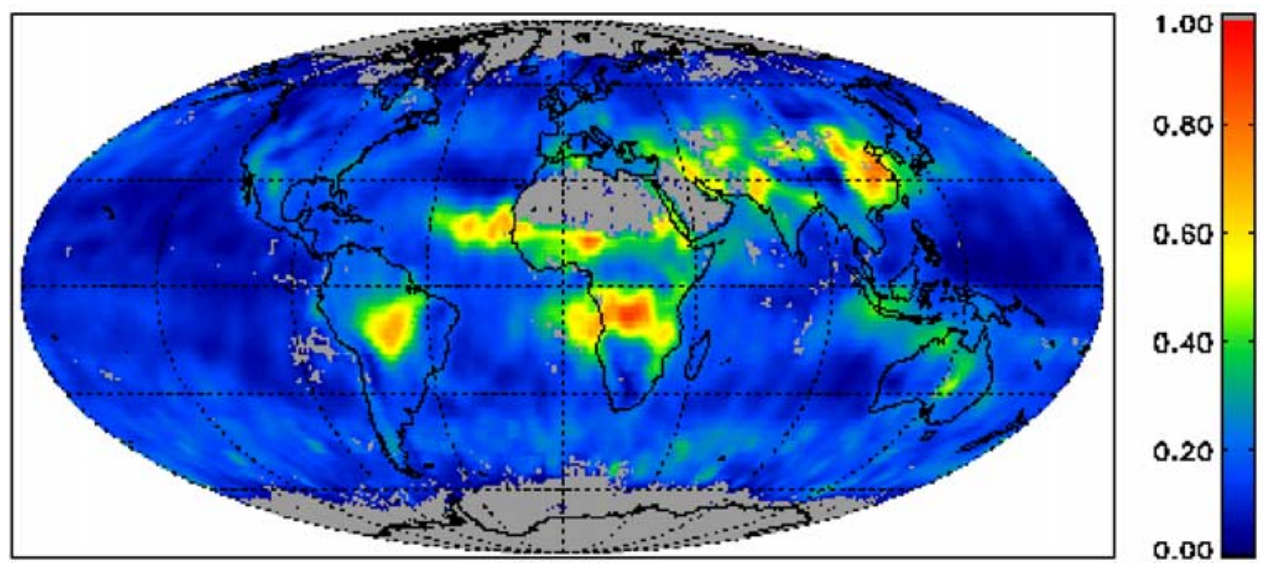

Figure 2. A global 8-days composite of MODIS aerosol optical thickness, $\tau_{\text {aer }}$, at $0.55 \mu \mathrm{m}$ starting on 21 September 2000, which corresponds to the time period of the SHADE experiment. The latest version of the MODIS aerosol algorithm (version 04) that includes a sophisticated cirrus cloud screening is used.

estimated as shown by Levy et al. [2003] during the PRIDE experiment.

\section{Description of the Meteorological and Dust Conditions}

[13] A global 8-days composite of MODIS aerosol optical thickness, $\tau_{\mathrm{aer}}$, at $0.55 \mu \mathrm{m}$ is given in Figure 2. The composite starts on 21 September 2000, which corresponds to the time period of the SHADE experiment. It is done with the latest available version of the MODIS aerosol algorithm (version 04) that includes a sophisticated cirrus cloud screening [Gao et al., 2002; Martins et al., 2002]. The most striking features are due to biomass burning activities in southern Africa and Brazil, pollution and/or dust over China and India and dust advecting from the African continent over the tropical Atlantic ocean. Because the desert surface (gray areas on Figure 2) is very bright, there is no retrieval over these regions [Kaufman et al., 1997]. Figure 2 clearly shows that dust activity was important in the SHADE operating region near the west coast of Africa. After a brief overview of the dust annual cycle in the region, the conditions during the experiment are described followed by the flight patterns in relation to the air mass trajectories.

\subsection{General Description}

[14] The location, the intensity and the frequency of the dust events are dependent on the season and on the meteorological conditions over sources areas [Chiapello et al., 1997]. As previously reported [see, e.g., Prospero and Carlson, 1972; Jaenicke and Schütz, 1978], the largest dust concentration over the equatorial Atlantic ocean is observed in summer time. More recently, this has been confirmed by the regular observations of the AERONET Sun photometer [Holben et al., 2001] installed in the Sal Island. In Figure 3, we show the monthly means over six years of the aerosol optical thickness, $\tau_{\text {aer }}$, (related to the dust atmospheric column loading) and of the Angstrom exponent (related to the size; smaller the values larger the aerosol size). $\tau_{\text {aer }}$ is relatively high throughout the year with more elevated values in summer (from May to September) and secondary peaks in winter (January-
February). The elevated values in summer with corresponding low Angstrom exponent indicates that the aerosol regime is dominated by frequent Saharan dust outbreaks. No significant contribution is expected from biomass burning because the seasonal nature of burning in the region means that most biomass burning do not take place in summer months. For instance, there is no fire north of the equator in September 2000 as reported by the map of burned areas (Figure 4a) [Grégoire et al., 2003]. The situation is different in wintertime. The relative high aerosol content associated with the low Angstrom parameters can still be attributed to dust with a possible contribution of the marine sea salt [Chiapello et al., 1997] but there is obviously in winter-early spring, a contribution from a different aerosol type as identified by the higher values of the Angstrom parameter. Chemical analysis from samples performed at ground level and air mass trajectory analysis suggest that there is possible pollution by sulfates coming from urban and industrial regions in north Africa or Europe [Chiapello et al., 1997]. It is also likely that aerosols resulting from biomass burning are present at that time of the year, due to the proximity of the biomass burning sources, like observed in December 2000 (Figure 4b). Therefore, while it is difficult to make definitive conclusions about the origin of the aerosol and the aerosol composition during the winter, it is expected that dust is the major contributor to the $\tau_{\text {aer }}$ during the summer with limited mixing of other aerosol types.

\subsection{Dust Conditions During the Experiment}

[15] The experiment took place between 19 and 29 September 2000. During that period, dust conditions were changing in the study area as shown in Figure 5 for Sal Island and M'Bour AERONET sites. $\tau_{\text {aer }}$ in Sal Island is increasing from 23 until 26 September where it is at a maximum. It corresponds to the same dust event that is measured in M'Bour where the maximum is reached on 25 September. The end of a previous event associated with little dust concentration can be noted on 20-21 September. The 22nd of September was cloudy for both sites all day long. Moderate concentrations were observed in M'Bour on 24 and 28 September. 

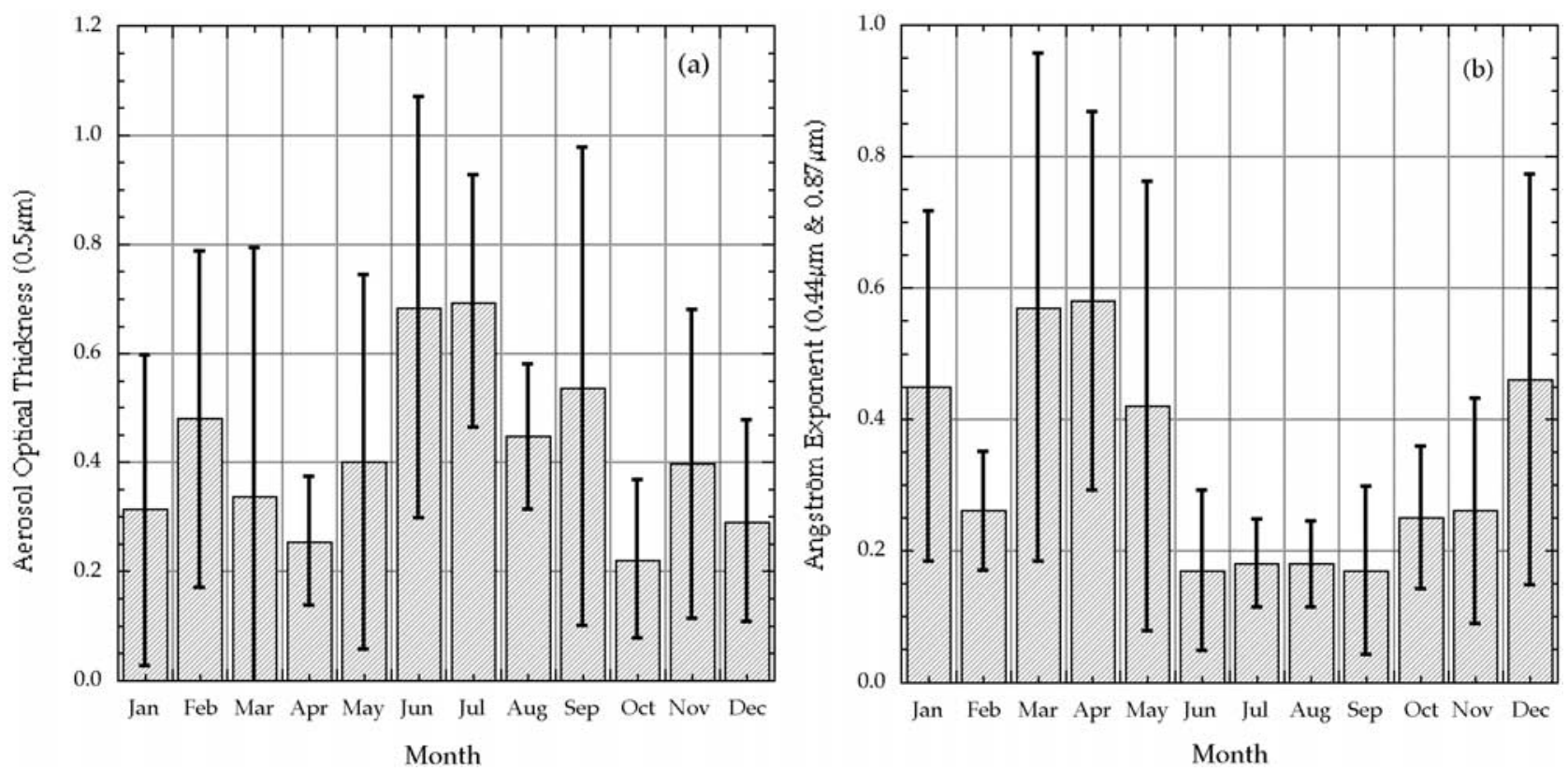

Figure 3. (a) Monthly mean over 1994-1999 of the aerosol optical thickness $\left(\tau_{\text {aer }}\right)$ at $0.550 \mu \mathrm{m}$ and (b) the Angstrom exponent measured in Cape Verde. The error bars show the standard deviation in the measurements.

[16] Figure 6 gives an image of the dust layer as seen from the M20 on 26 September. The ocean surface is occulted due to the large optical depth of the dust layer, and some altocumulus are seen to develop at the top of the layer with small vertical extent and limited optical depths. SEAWifs images corresponding to the major event on 2526 September are provided on Figure 7 . They clearly show the importance of the event that extends over several hundred of $\mathrm{km}^{2}$ and is advected westward off the coast of west Africa. Details of the daily evolution of $\tau_{\text {aer }}$ at a wavelength of $0.67 \mu \mathrm{m}$ are shown on Figure 8. In M'Bour (Figure 8a), $\tau_{\text {aer }}$ is moderate on 24 September around 0.40, very large on 25 September around 1.50 , and slightly decreases in the afternoon to reach 1.20. In Sal Island (Figure $8 \mathrm{~b}$ ), the value is rather constant on 25 September, around 0.50 . On 26 September, the dust outbreak is passing over Sal Island with a maximum of 1.70 at 9:00UT, then a decrease of a factor 3 between the morning and the afternoon is observed.

\subsection{Description of the Flights}

[17] The flight plans were designed to have both aircrafts taking measurements over surface sites and during TERRA overpasses. The C-130 aircraft made stepped profile ascents or descents in close proximity to the ground-based instrumentation. It also performed profile descents (or ascents) over the ocean below the M20 at the time of the TERRA satellite overpass and straight and level runs (SLRs) at various altitudes within the dust layer. The M20 aircraft performed stepped profiles around the ground-based instrumentation as well as straight runs over the ocean at higher altitudes (around 12,000 m) to fly above the aerosol layer.

[18] The flight time for both aircraft and the corresponding dust conditions are reported in Table 1. The flight patterns are reported in Figure 9a for the C-130 and in
Figure $9 \mathrm{~b}$ for the M20. Among the 7 flights, 25 September was selected as the "golden" day of the experiment. The C-130 flew over area between Sal Island and M'Bour surface sites. Flight tracks are co-incident with the M20 and with a TERRA overpass. On the 26th, the dust conditions were excellent, the M20 flew above the dust plume and the MODIS data were acquired simultaneously. Unfortunately, in situ measurements could not be performed due to a problem with the C-130 engine. Nevertheless, 26 September is the best day for the remote sensing objectives of SHADE. During the remaining days, in situ sampling of the physical, chemical and radiative properties of the dust was performed but the meteorological conditions were not optimum and the satellite images are cloud contaminated. The M20 flights on 27 and 28 September are not discussed because of the presence of low and high clouds in the aerosol field.

\subsection{Air Mass Origins}

[19] The general situation is analyzed for the two days with highest $\tau_{\text {aer }}$, i.e., in M'Bour on the 25 September and in Sal Island on the 26 September. The analysis is based on back-trajectories (Figure 10) derived from the Met Office Lagrangian dispersion Nuclear Accident Model (NAME) [Ryall and Maryon, 1998]. NAME uses ambient mean winds from the Met Office numerical weather prediction model for advection, and its performance has been verified for dust events originating from the Sahara [Ryall et al., 2002]. The aerosol index (AI) from the TOMS instrument on Earth Probe (Figure 11) is used to locate the dust sources and the Lidar data [Léon et al., 2003] to derive the altitude of the aerosol layer.

[20] On 25 September, the presence of the Saharan Aerosol Layer (SAL) over M'Bour is clearly shown by the in situ and radiation measurements from the C-130 [Haywood et al., 2003] and the Lidar measurements from 

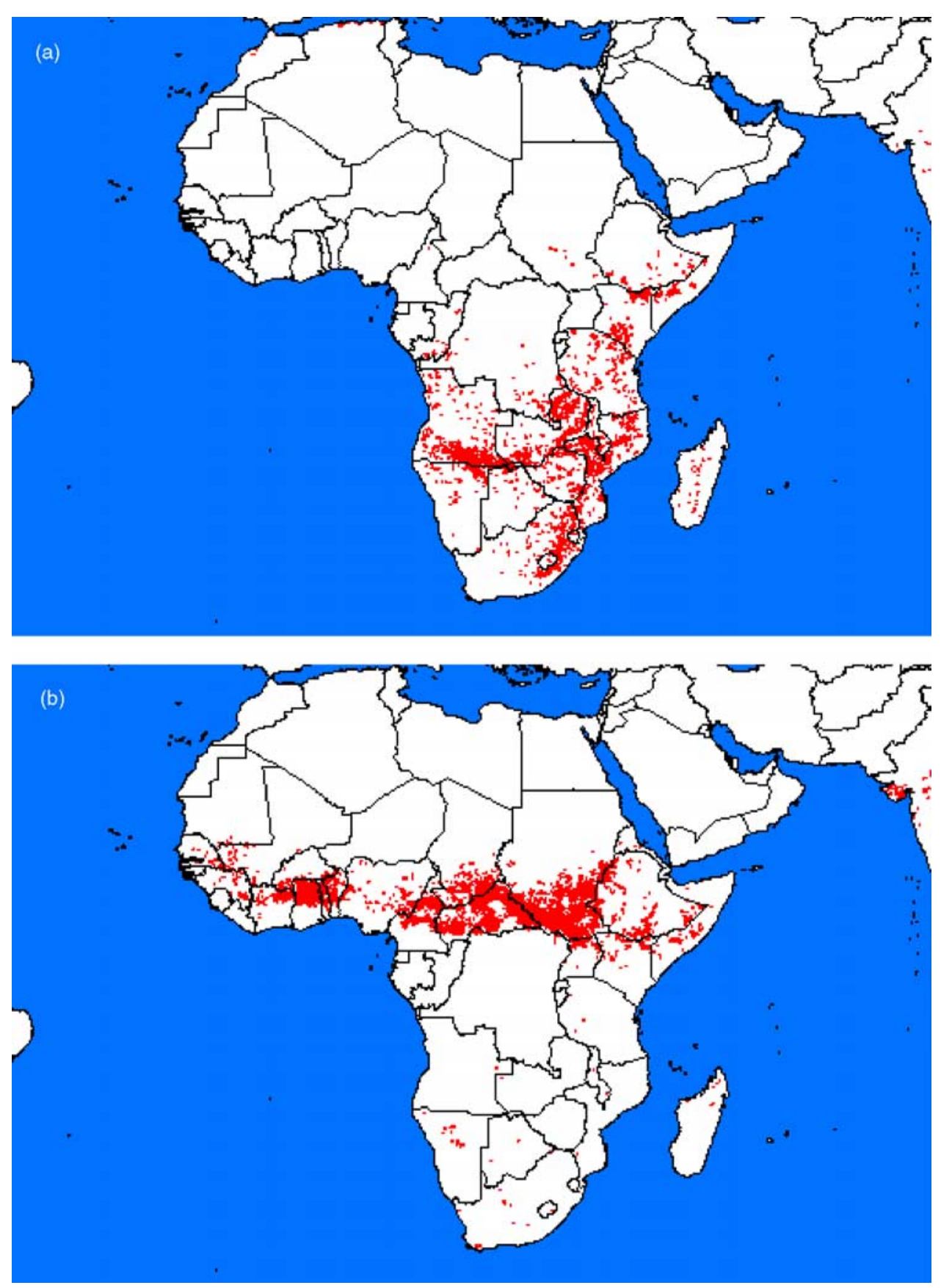

Figure 4. Map of burned areas for (top) September 2000 and (bottom) December 2000 from SPOTVegetation (http://www.grid.unep.ch/activities/earlywarning/preview/ims/gba/).

the M20 [Léon et al., 2003]. Elevated extinction is measured between 800 and $1800 \mathrm{~m}$ in the in situ data from the nephelometer on board the C-130 [Haywood et al., 2003] which is also observed from the Lidar. The corresponding aerosol layer is well-spread over the area. There is also a second layer located between 3000 and $4000 \mathrm{~m}$ but is less uniformly distributed. The trajectory analyses and the TOMS AI suggest that the aerosols present at $1500 \mathrm{~m}$ originates from west Mauritania (Figures 10a and 11). The higher aerosol layer originates from southern Algeria which confirms the difference of altitude of the dust transport, depending on the location of the sources [Chiapello et al., 1997].
[21] On 26 September, a deep aerosol dust layer is located over Sal Island between 2000 and 3000m [Léon et al., 2003]; the back-trajectory analyses suggest that it originates from northeast Mauritania and west Algeria (Figures 10b and 11). There is still a layer located around $1000 \mathrm{~m}$ whose the origin is mixed and at higher altitudes, the aerosols continue to originate from southern Algeria.

\section{Main Results of SHADE Campaign}

[22] Hereinafter, we provide an overview of the main results obtained during SHADE. For a complete description and critical analysis of the results the reader should refer to 


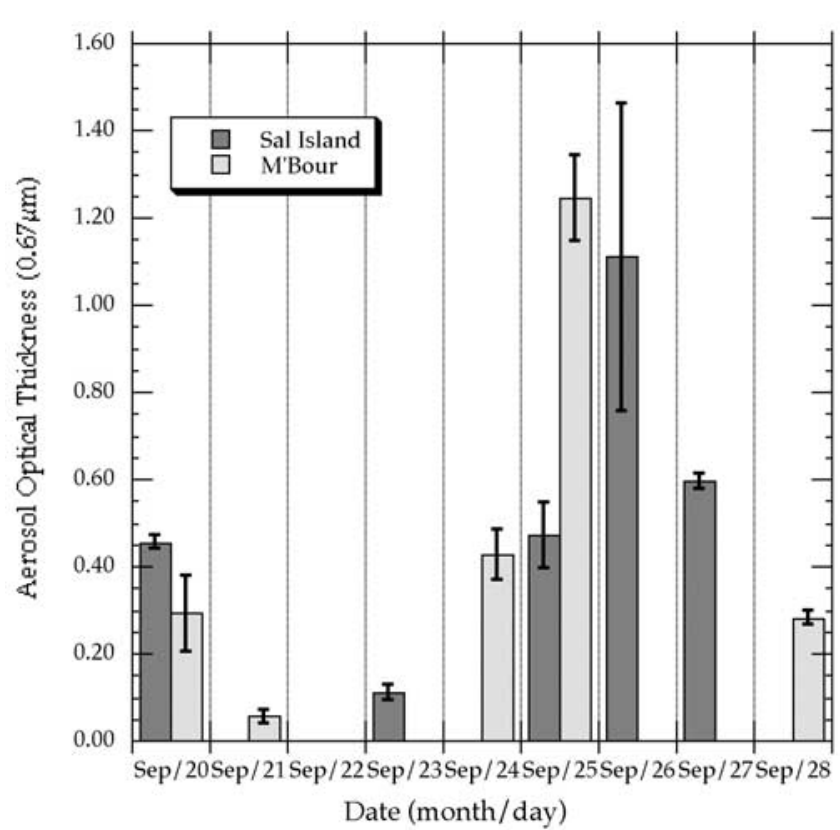

Figure 5. Evolution of the aerosol optical thickness $\left(\tau_{\text {aer }}\right)$ at $0.670 \mu \mathrm{m}$ between 20 and 28 September 2000 in Sal Island and M'Bour. The error bars show the standard deviation in the measurements. Some days are missing because of the presence of clouds.

the original papers included in this special issue, namely Formenti et al. [2003], Haywood et al. [2003], Highwood et al. [2003], Léon et al. [2003], Myhre et al. [2003].

\subsection{Physical and Optical Properties of Dust}

[23] The aerosol composition was obtained using filter samples collected from the C-130 [Formenti et al., 2003] and is consistent with previous results in the area [Chiapello et al., 1997]. Based on the chemical analysis, the aerosols present during the experiment were not contaminated by biomass burning aerosols, and in a minor but detectable way by anthropogenic pollution. The aerosol properties that are derived are therefore representative of Saharan dust although the regions of origin of the dust may vary.

[24] The size distributions were derived from the in situ measurements [Haywood et al., 2003] and from the groundbased measurements, using inversion schemes developed by Nakajima et al. [1996] and Dubovik et al. [2002a]. Despite the surface measurements give column integrated size distribution when the in situ measurements provide the distribution collected at a given altitude, the comparison is rather good [Highwood et al., 2003]. The results are also in good agreement with previous studies [Tanré et al., 2001] that showed that dust offshore Sénégal has a double-peaked size distribution centered at roughly $0.40 \mu \mathrm{m}$ and $1.5-2.0 \mu \mathrm{m}$. The nonsphericity of dust on the inversion scheme that results in an artificial increase in the size distribution at $0.1 \mu \mathrm{m}$ using the classical inversion proposed by Dubovik et al. [2002a] can be solved using spheroids [Dubovik et al., 2002b].

[25] Although there are several efforts for modeling the mineralogy of dust [Claquin et al., 1999; Sokolik et al., 1998], there are still few published values of the refractive index of Saharan dust measured in the thermal infrared spectral region. Since these values control the radiative forcing and the three most quoted references [Volz, 1973; World Meteorological Organization (WMO), 1983; Fouquart et al., 1987] are very different, we can use the SHADE data to suggest the most appropriate data set. To do so, our approach was to check the consistency of the brightness temperatures measured by the ARIES instrument with simulated values using the three sets [Highwood et al., 2003]. The best agreement was observed when values given by Fouquart et al. [1987] are used. Those values, derived from an experiment in Niger during the dry season near the sources, also appear representative of dust transported over longer distances.

[26] Regarding the solar part of the spectrum, the real part of the refractive index was not measured. Usually, people use values suggested by $W M O$ [1983]. These values are used in the study of Haywood et al. [2003] and the measured and modeled optical properties appear consistent. Recent values obtained from remote sensing [Tanré et al., 2001] did also confirm the coherency of WMO values except in the shortwave IR (at $2.1 \mu \mathrm{m}$ ) where the value (1.20) is clearly an underestimate and 1.40 is better for obtaining consistency with radiative measurements.

[27] Concerning the imaginary part of the refractive index, local closure studies whereby light scattering and absorption are measured in situ by the nephelometer and PSAP suggest that the WMO values of the imaginary part of the refractive index are clearly too high in the solar spectrum and are therefore inconsistent with our measurements [Haywood et al., 2003]. Our measurements suggest much less absorption, which confirms previous values recently derived by Kaufman et al. [2001], i.e., $0.90 \pm 0.02$ in the blue, $0.97 \pm 0.02$ at $0.670 \mu \mathrm{m}$ and almost no absorption in the solar near infrared. This is a very important result since, using the new values, the direct radiative effect of dust can go from a warming effect to a cooling effect depending on the surface albedo [Myhre et al., 2003].

[28] Column radiative closure studies that determine the aerosol optical depth are reported by Haywood et al. [2003]. Comparison of these measurements to those derived from

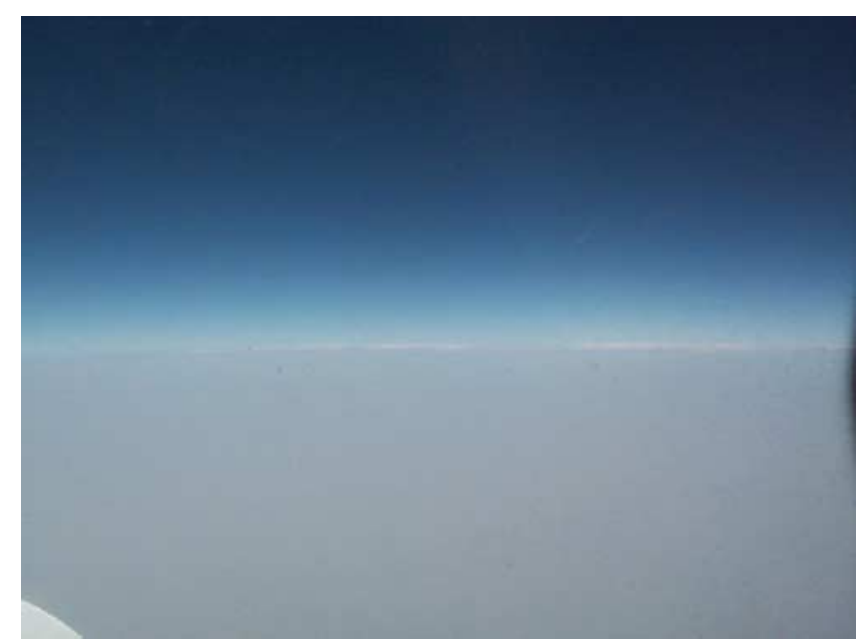

Figure 6. Observation of the dust layer from the Mystere 20 on the 26 September near the middle of the north-south leg. 
(a)

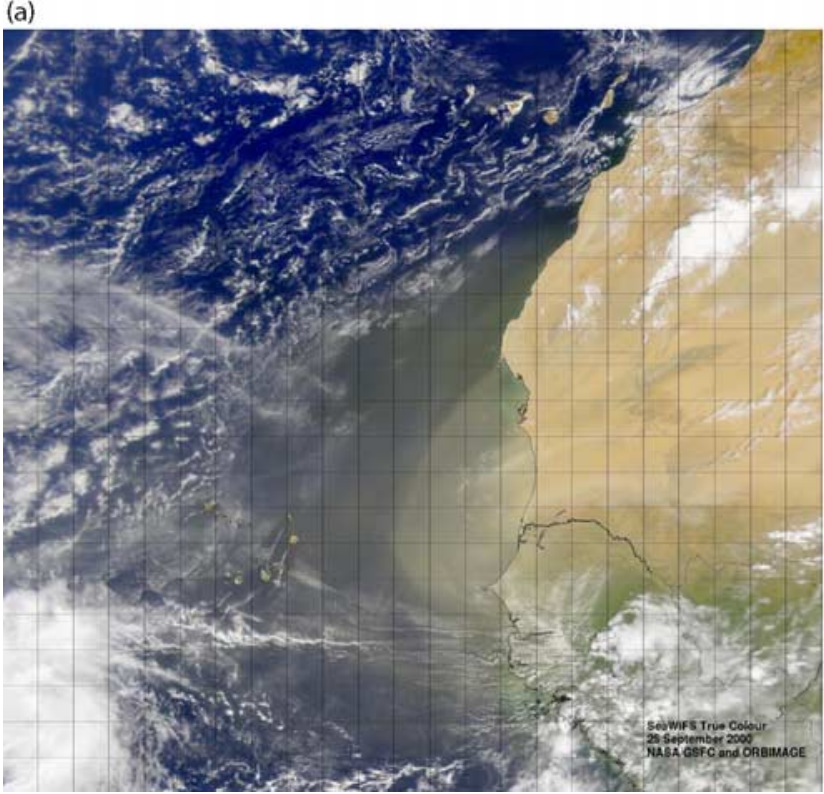

(b)

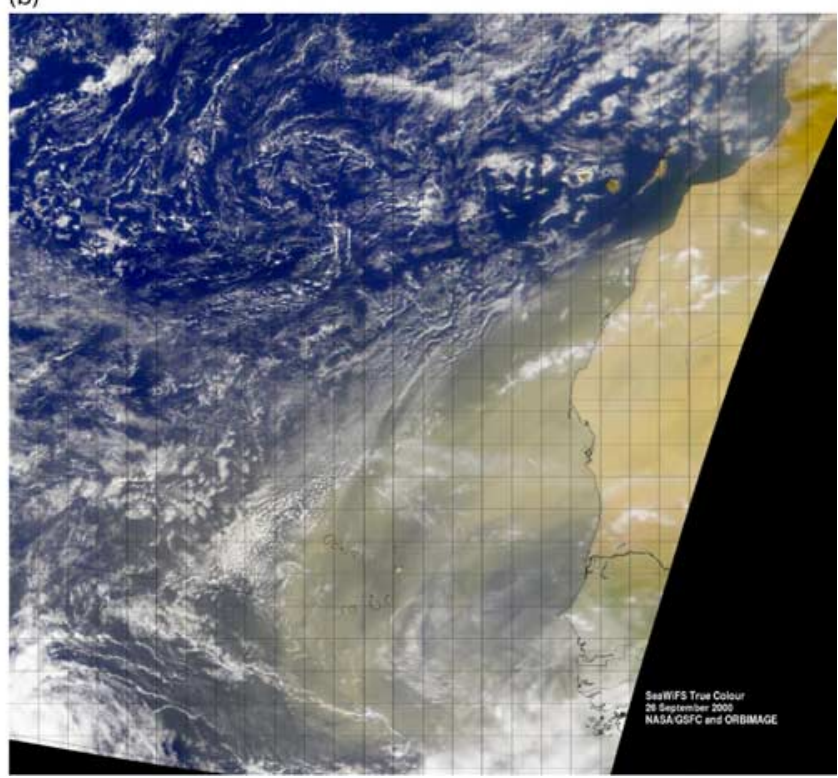

Figure 7. True color composite of SEAWifs images acquired on (a) 25 and (b) 26 September 2000 over the tropical Atlantic ocean near the west African coast.

surface based Sun photometers suggest that the in situ integration of the nephelometer and PSAP measurements significantly underestimates the aerosol optical depth due to the collection efficiency of the inlet being significantly reduced for supermicron sized dust particles. Haywood et al. [2003] derive a multiplicative correction factor of 1.5 to account for this problem, but the aerosol optical depth derived in this way is still subject to large uncertainties. A new low-turbulence aerosol inlet is being designed to alleviate the problems of sampling supermicron aerosol particles. The aerosol optical depths derived from broadband and spectral radiometric measurements from the C-130 show excellent agreement with the aerosol optical depths derived from the surface based Sun photometers.

\subsection{Dust Forcing (Direct)}

[29] The direct radiative effect (DRE) is defined by the upwelling irradiance in the absence of dust minus the upwelling irradiance in dusty conditions. Negative radiative effects therefore indicate an enhancement in the planetary albedo. The direct radiative effect was shown to reach instantaneous values of approximately $-130 \mathrm{~W} \mathrm{~m}^{-2}$ over ocean in the solar spectrum on 25 September [Haywood et al., 2003], which is very large compared to other aerosol types
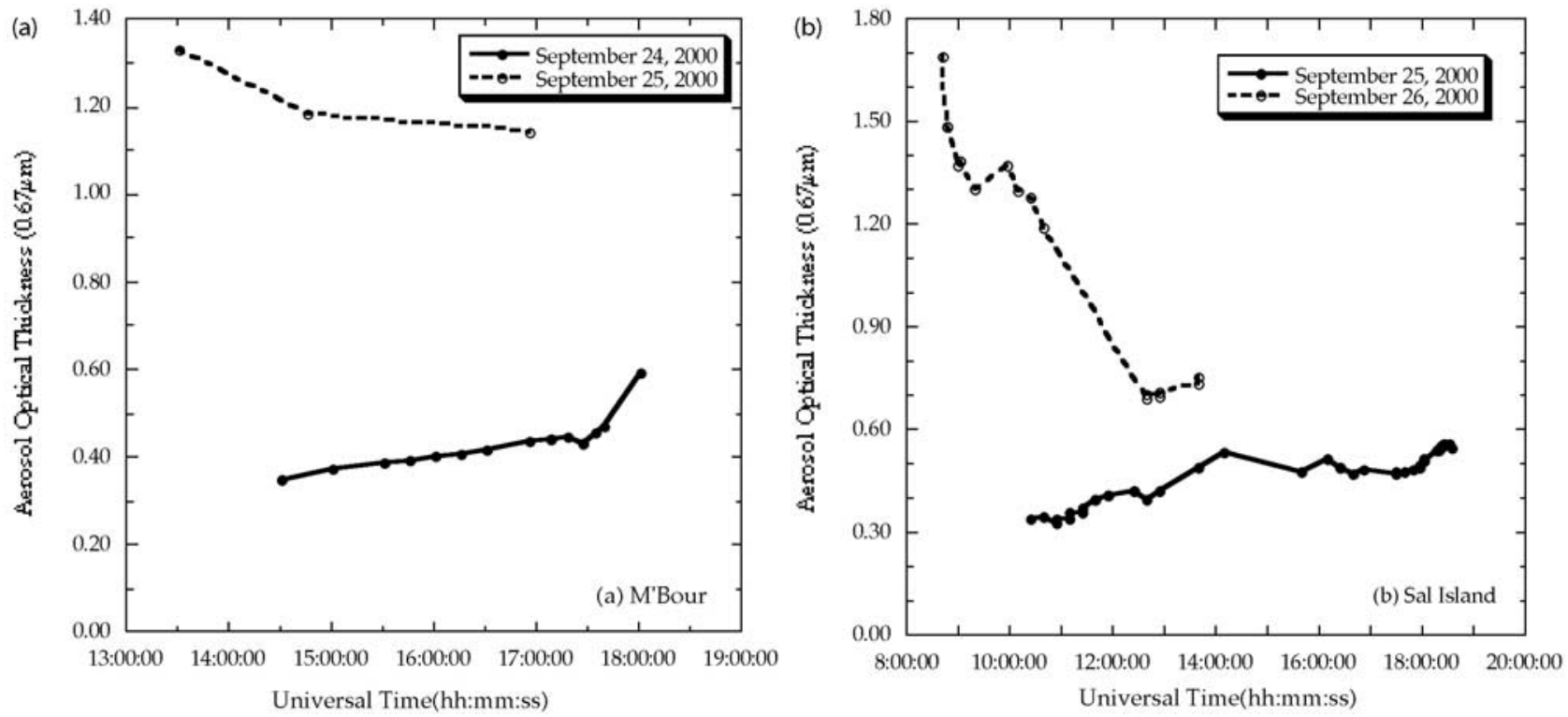

Figure 8. (a) Daily evolution of the aerosol optical thickness $\left(\tau_{\text {aer }}\right)$ at $0.67 \mu \mathrm{m}$ during SHADE in M'Bour on 24 and 25 September 2000. The vertical error bars show the standard deviation in the measurements. (b) Same as in Figure 8a but on 25 and 26 September in Sal Island. 
Table 1. Description of the Seven Flights Over the Sea Areas Around Sal Island and M'Bour ${ }^{\mathrm{a}}$

\begin{tabular}{|c|c|c|c|c|c|}
\hline \multirow[b]{2}{*}{ Day } & \multirow[b]{2}{*}{ M20 } & \multirow[b]{2}{*}{ C-130 } & \multirow[b]{2}{*}{ MODIS } & \multicolumn{2}{|c|}{ Dust Conditions in Uncloudy Areas } \\
\hline & & & & Sal Island & M'Bour \\
\hline 09/21 & $\begin{array}{l}15 \mathrm{~h} 50-18 \mathrm{~h} 15 \\
\text { transit from Canaries to } \\
\text { Sal Island }\end{array}$ & $\begin{array}{l}08 \mathrm{~h} 25-17 \mathrm{~h} 38 \\
\text { from Sal Island to } \\
\text { Canaries }\end{array}$ & $11 \mathrm{~h} 45$ partly cloudy & $\begin{array}{c}08 \mathrm{~h} 35-10 \mathrm{~h} 00 \\
\min =0.65(1 \mathrm{pt}) \\
\max =0.99(1 \mathrm{pt})\end{array}$ & $\begin{array}{r}08 \mathrm{~h} 00-18 \mathrm{~h} 00 \\
\min =0.08 \\
\max =0.16\end{array}$ \\
\hline $09 / 24$ & grounded & $\begin{array}{l}\text { 08h24-18h28 } \\
\text { from Sal Island to } \\
\text { M'Bour }\end{array}$ & $12 \mathrm{~h} 15$ glint & $\begin{array}{c}08 \mathrm{~h} 10-16 \mathrm{~h} 40 \\
\min =0.25 \\
\max =0.35\end{array}$ & $\begin{array}{c}08 \mathrm{~h} 00-18 \mathrm{~h} 20 \\
\min =0.36 \\
\max =0.61\end{array}$ \\
\hline $09 / 25$ & $\begin{array}{l}\text { 15h34-18h06 } \\
\text { from Sal Island to } \\
\text { M'Bour }\end{array}$ & $\begin{array}{l}\text { 08h24-18h28 } \\
\text { from Sal Island to } \\
\text { M'Bour }\end{array}$ & $11 \mathrm{~h} 20$ edge & $\begin{array}{c}10 \mathrm{~h} 00-18 \mathrm{~h} 40 \\
\min =0.32 \\
\max =0.57\end{array}$ & $\begin{array}{r}11 \mathrm{~h} 00-18 \mathrm{~h} 00 \\
\min =0.85 \\
\max =1.55\end{array}$ \\
\hline $09 / 26$ & $\begin{array}{l}11 \mathrm{~h} 07-13 \mathrm{~h} 59 \\
\text { from Sal Island to } \\
\text { Nouadhibou }\end{array}$ & grounded & $11 \mathrm{~h} 20$ & $\begin{array}{c}08 \mathrm{~h} 40-17 \mathrm{~h} 10 \\
\min =0.60 \\
\max =1.70\end{array}$ & $\begin{array}{c}08 \mathrm{~h} 00-14 \mathrm{~h} 00 \\
\min =0.28 \\
\max =0.80\end{array}$ \\
\hline $09 / 27$ & $\begin{array}{l}\text { 11h41-13h53 } \\
\text { from Sal Island to } \\
\text { north }\end{array}$ & grounded & $12 \mathrm{~h} 45$ partly cloudy & $\begin{array}{c}16 \mathrm{~h} 20-18 \mathrm{~h} 50 \\
\min =0.55 \\
\max =0.65\end{array}$ & no data \\
\hline $09 / 28$ & $\begin{array}{l}12 \mathrm{~h} 21-15 \mathrm{~h} 5 \\
\text { from Sal Island to } \\
\text { north }\end{array}$ & $\begin{array}{l}07 \mathrm{~h} 29-17 \mathrm{~h} 11 \\
\text { from Sal Island to } \\
\text { north }\end{array}$ & 11 h50 mostly cloudy & no data & $\begin{aligned} & 13 \mathrm{~h} 00-17 \mathrm{~h} 00 \\
& \min =0.28 \\
& \max =0.35\end{aligned}$ \\
\hline 09/29 & $\begin{array}{l}07 \mathrm{~h} 00-09 \mathrm{~h} 00 \text { transit } \\
\text { from Sal Island to } \\
\text { Canaries }\end{array}$ & $\begin{array}{l}05 \mathrm{~h} 51-07 \mathrm{~h} 00 \text { transit } \\
\text { from Sal Island to } \\
\text { Canaries }\end{array}$ & $12 \mathrm{~h} 30$ & $\begin{array}{c}08 \mathrm{~h} 00-14 \mathrm{~h} 00 \\
\min =0.30 \\
\max =0.40\end{array}$ & $\begin{array}{r}09 \mathrm{~h} 30-14 \mathrm{~h} 30 \\
\min =0.60 \\
\max =0.66\end{array}$ \\
\hline
\end{tabular}

${ }^{\mathrm{a}}$ The time of the flights is reported for each aircraft as well as the conditions of the MODIS data acquisition. Dust conditions are summarized for the two surface sites.

[IPCC, 2001]. Given the measured $\tau_{\text {aer }}$ at $0.55 \mu \mathrm{m}$ of approximately 1.5 , the normalized direct radiative effect is approximately $-90 \mathrm{~W} \mathrm{~m}^{-2}$ per unit aerosol optical thickness. At the surface level, the radiative impact is around 1.6 times that at the top of the atmosphere, which is smaller than recent results derived during the Indian Ocean Experiment (INDOEX), which yielded values between 2 and 3 [Ramanathan et al., 2001; Léon et al., 2002]. This is due to the relatively high value of the single scattering albedo during SHADE. In the terrestrial spectrum, the dust impact is of order of $10 \%$ of the solar impact but will always be of positive sign [Highwood et al., 2003; Myhre et al., 2003]. In term of temperature change, a maximal reduction of about $1.5 \mathrm{~K}$ in brightness temperature was observed from the M20 radiometry data at the top of the dust layer using PRT5 measure- ments in the $8-14 \mu \mathrm{m}$ wavelength domain for a plane albedo increase of about $15 \%$ as compared to clear air conditions.

[30] The Oslo chemical transport model (Oslo CTM2) was used for estimating the impact of dust at the regional scale [Myhre et al., 2003]. The model is driven by meteorological data from ECMWF during the SHADE period and the actual meteorological data are also used in the dust production by applying the friction velocity. First of all, the model is able to reproduce the horizontal and vertical spatial distributions observed during the experiment, including reasonable agreement with the aerosol optical depths at the AERONET sites shown in Figure 5. The optical and physical properties of the dust model agree well with the observations, which gives us good confidence in the radiative computations. The regional solar diurnal mean
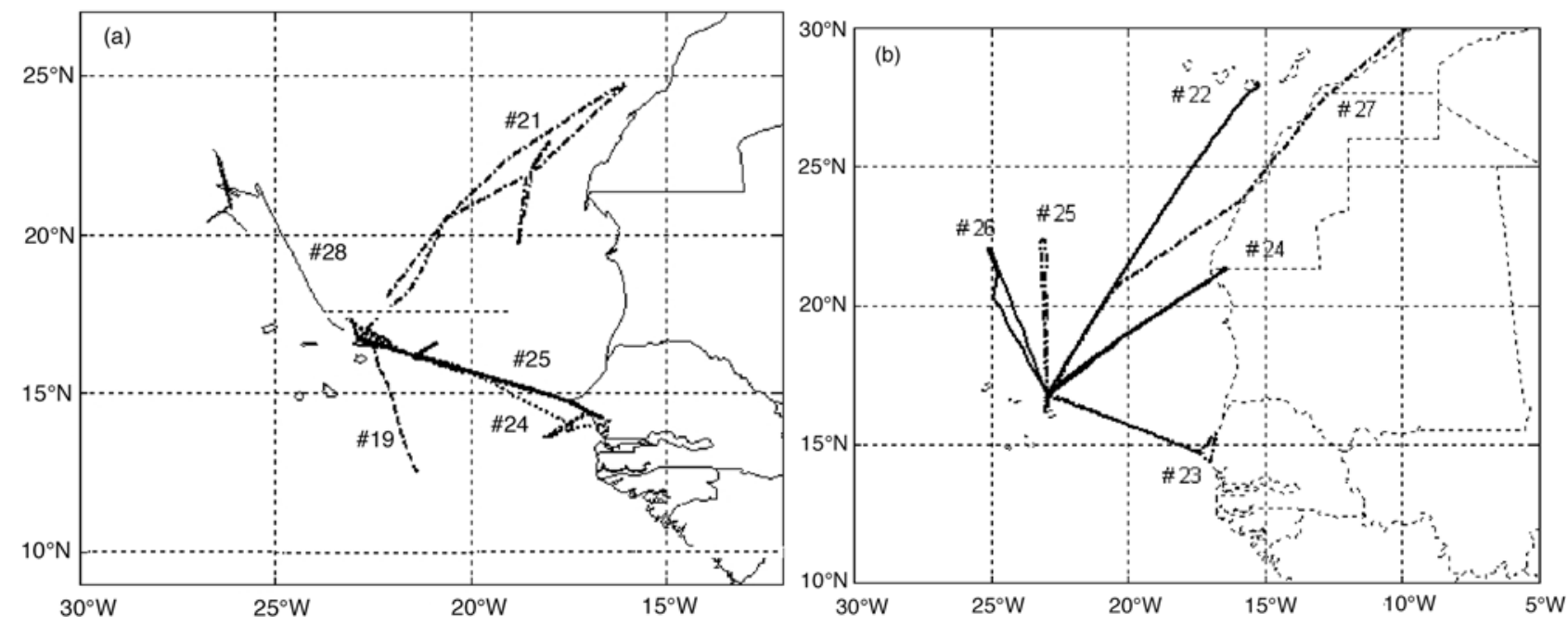

Figure 9. (a) Flight pattern of the C-130. The flights are indexed by days 19, 21, 24, 25, and 28 September. (b) Flight pattern of the M20. The flights are indexed by flights numbers (from 22 to 27) that correspond to the following days, 21, 25, 26, 27, 28, and 29 September. 

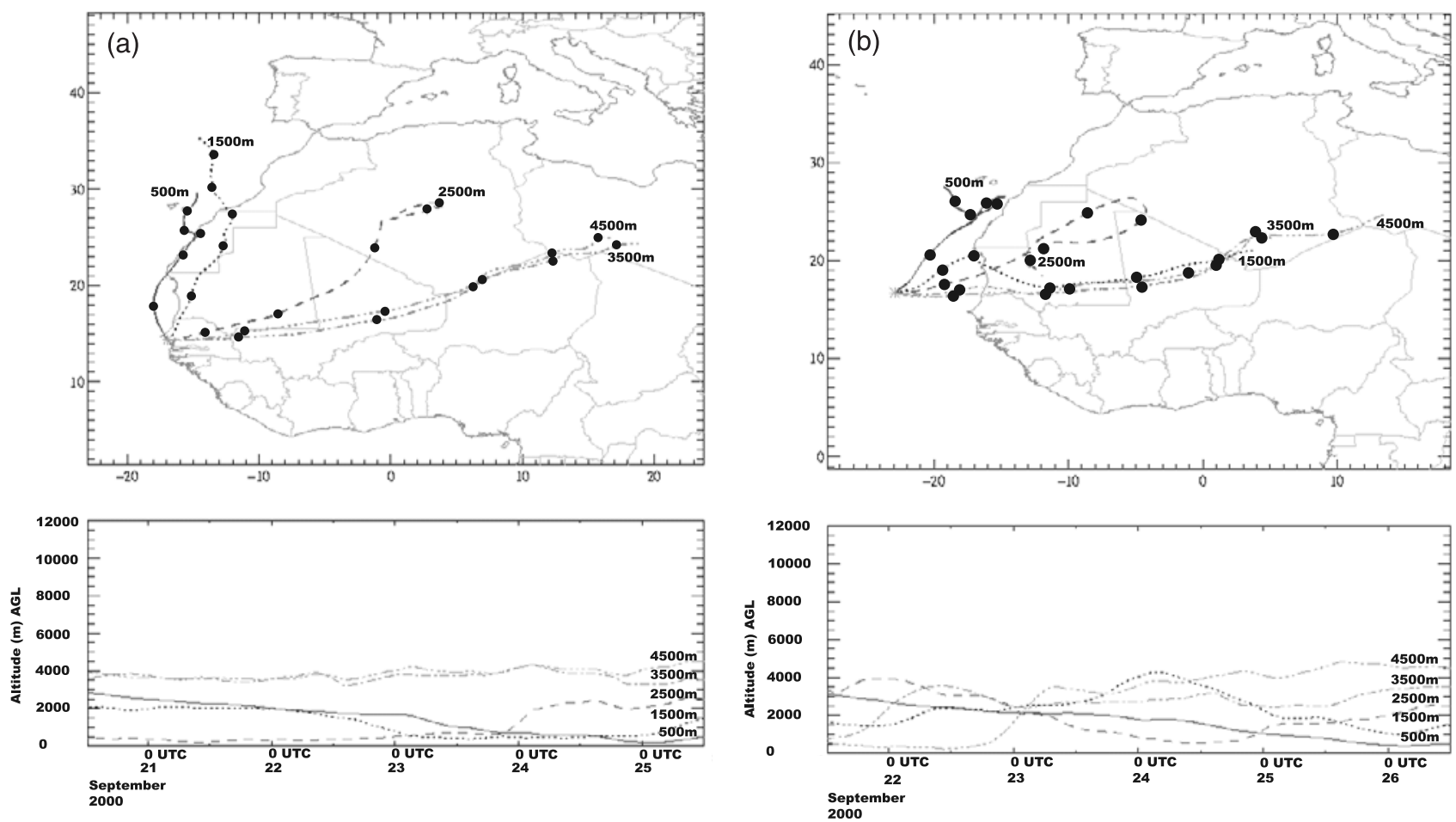

Figure 10. (a) Backward air mass trajectories over 5 days initialized at M'Bour, Sénégal, on 25 September for five altitudes, 500, 1500, 2500, 3500, and 4500m. Each dot corresponds to the position at $00 \mathrm{~h} 00$. (b) Same as Figure 10a but for the 26 September at Sal Island.

radiative impact during SHADE in an area around the Sahara (latitudes between $0^{\circ} \mathrm{N}-30^{\circ} \mathrm{N}$ and longitude between $60^{\circ} \mathrm{W}-40^{\circ} \mathrm{E}$ ) was estimated to be around $-8.0 \sim$ $10.0 \mathrm{~W} \mathrm{~m}^{-2}$ for clear skies and around $-6.0 \mathrm{~W} \mathrm{~m}^{-2}$ when clouds are considered with a corresponding impact in the terrestrial spectrum of $+1.0 \sim 1.2 \mathrm{~W} \mathrm{~m}^{-2}$ and $+0.7 \sim$ $0.9 \mathrm{~W} \mathrm{~m}^{-2}$ respectively. The global and diurnal mean net radiative impact of the Saharan dust storm examined in this study during SHADE is estimated as approximately $-0.4 \mathrm{~W} \mathrm{~m}^{-2}$.

\subsection{Active and Passive Remote Sensing Observations}

[31] The combination of active and passive remote sensing observations brings a new dimension into characterization of aerosol properties since, instead of getting column integrated parameters, vertical information can be derived [Kaufman et al., 2003]. While Lidar data are suitable for providing the vertical distribution of the backscattered coefficients, and the location of aerosol layers, the information at two wavelengths is insufficient to give vertically distributed physical properties such as the effective radius over ocean. Passive spectral data (i.e., MODIS) [Tanré et al., 1997] or passive polarized data (i.e., POLDER) [Deuzé et al., 2000] provide information on the aerosol size distribution, but they cannot give any information on the vertical distribution. However, within the A-Train, as aerosol properties derived from the MODIS are planned to be obtained in conjunction with Lidar measurements, one can take advantage of the Lidar spectral information on the vertical.

[32] From SHADE, we showed that the profile of extinction coefficient compare very well with the in situ data.
Regarding the size distribution, the effective radius can also be determined as a function of the altitude [Léon et al., 2003]. In the aerosol layer, between $2500 \mathrm{~m}$ and $4500 \mathrm{~m}$ on 26 September, particles with effective radius as large as $1.2 \mu \mathrm{m}$ are present. We do not have in situ validation data for this parameter but the retrieved values appears representative of the dust size and the variability of particle size with height is confirmed by in situ data [Formenti et al., 2003].

\section{Conclusion}

[33] The dust physical and optical properties were derived during SHADE, with concurrent measurements of the radiances and irradiances within the solar and the terrestrial spectrum. A good consistency between the various measurements and the results of the modeling is observed. It validates both the modeling and the dust properties on which the computations of the chemical tranport model are based. Results from SHADE strongly suggest that the mineral dust has a cooling effect and the model estimates a global net DRE of the Saharan dust of $-0.4 \mathrm{~W} \mathrm{~m}^{-2}$. Note that this estimate includes only Saharan dust and the anthropogenic fraction of this is very uncertain.

[34] Concerning the use of satellite for aerosol remote sensing, the new sensors explicitly designed for that objective are efficient. The combination of passive and active observations is very powerful. The location of the aerosol layer within the atmospheric column can be determined and properties like the effective radius can be derived as a function of the altitude, which is very important to understand the indirect aerosol effect. 

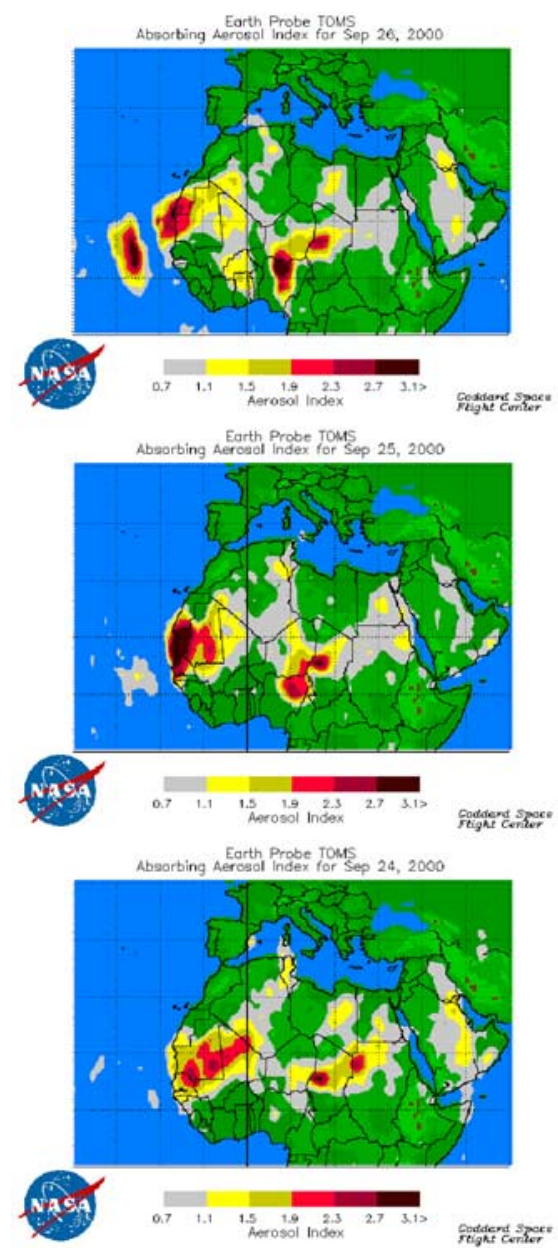
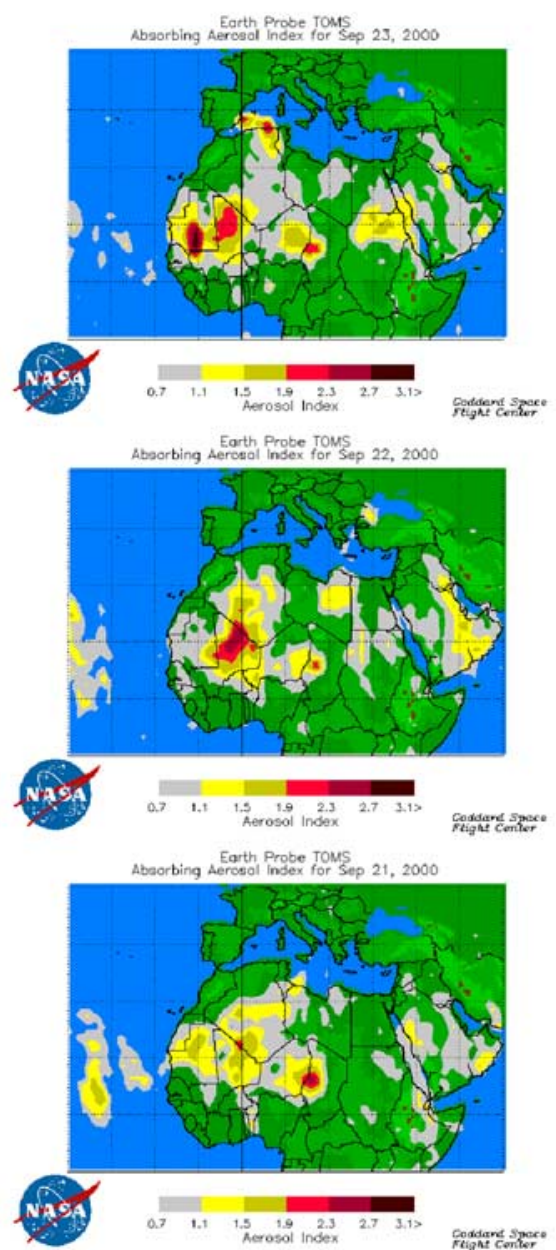

Figure 11. TOMS aerosol index images from (top) 26 September to (bottom) 24 September on the left panel and from (top) 23 September to (bottom) 21 September on the right panel (see http://toms. gsfc.nasa.gov/aerosols/aerosols.html).

[35] The results from SHADE concern unpolluted dust aerosols. Depending on the season, dust may be mixed with biomass burning aerosols. It results in different optical properties like the single scattering albedo that states the sign of the direct effect. There is still a need for characterizing the dust properties during these specific conditions to assess the overall aerosol effects in that region.

[36] Acknowledgments. The crew and support staff of the Met Office MRF and INSU/M20 are thanked for their efforts during and after the measurement campaign. The authors acknowledge the PHOTONS/ AERONET team for processing the ground-based aerosol observations, F. Lavenu for his help in installing the M'Bour site and J.Y. Balois for operating the POLDER instrument on the M20. They also thank Li Rong-Rong for providing the map of the MODIS aerosol optical thickness, Slobodan Nickovic and Yves Balkanski for their contribution in the dust forecast during the experiment and the TOMS group at NASA/GSFC for providing the aerosol index. In addition, they wish to express their gratitude to the Servico National de Meteorologia e Geophysica (SNMG), Cape Verde, for their support during the experiment. This research was partly funded by the Centre National d'Etudes Spatiales in France and the Max Planck Society, Munich, Germany.

\section{References}

Chiapello, I., G. Bergametti, B. Chatenet, P. Bousquet, F. Dulac, and E. Santos Soares, Origins of African dust transported over the northeastern tropical Atlantic, J. Geophys. Res., 102, 13,701-13,709, 1997.
Claquin, T., M. Schulz, and Y. J. Balkanski, Modeling the mineralogy of atmospheric dust sources, J. Geophys. Res., 104, 22,243-22,256, 1999. Deschamps, P. Y., F. M. Bréon, M. Leroy, A. Podaire, A. Bricaud, J. C. Buriez, and G. Sèze, The POLDER mission: Instrument characteristics and scientific objectives, IEEE Trans. Geosci. Remote Sens., 32, 598615,1994

Deuzé, J. L., P. Goloub, M. Herman, A. Marchand, G. Perry, S. Susana, and D. Tanré, Estimate of the aerosol properties over the ocean with POLDER, J. Geophys. Res., 105, 15,329-15,346, 2000.

Dubovik, O., B. N. Holben, T. F. Eck, A. Smirnov, Y. J. Kaufman, M. D. King, D. Tanré, and I. Slutsker, Variability of absorption and optical properties of key aerosol types observed in worldwide locations, J. Atmos. Sci., 59, 590-608, 2002a.

Dubovik, O., B. N. Holben, T. Lapyonok, A. Sinyuk, M. I. Mishchenko, P. Yang, and I. Slutsker, Nonspherical aerosol retrieval method employing light scattering by spheroids, Geophys. Res. Lett., 29(10), 1415, doi:10.1029/2001GL014506, 2002b.

Formenti, P., W. Elbert, W. Maenhaut, J. M. Haywood, and M. O. Andreae, Chemical composition of mineral dust aerosol during the Saharan Dust Experiment (SHADE) airborne campaign in the Cape Verde region, September 2000, J. Geophys. Res., 108(D18), doi:10.1029/2002JD002648, in press, 2003.

Fouquart, Y., B. Bonnel, G. Brogniez, J. C. Buriez, L. Smith, and J. J. Morcrette, Observations of Saharan aerosols: Results of ECLATS field experiment. part II: Broadband radiative characteristics of aerosols and vertical flux divergence, J. Clim. Appl. Meteorol., 26, 38-52, 1987.

Francis, P. N., P. Hignett, and J. P. Taylor, Aircraft observations and modeling of sky radiance distributions from aerosol during TARFOX, J. Geophys. Res., 104, 2309-2319, 1999.

Gao, B.-C., Y. Kaufman, D. Tanré, and R.-R. Li, Distinguishing tropospheric aerosols from thin cirrus clouds for improved aerosol retrievals 
using the ratio of $1.38-\mu \mathrm{m}$ and $1.24-\mu \mathrm{m}$ channels, Geophys. Res. Lett., 29(18), 1890, doi:10.1029/2002GL015475, 2002.

Grégoire, J.-M., K. Tansey, and J. M. N. Silva, The GBA2000 initiative: Developing a global burned area database from SPOT-VEGETATION imagery, Int. J. Remote Sens., 24, 1-8, 2003.

Hansen, J., M. Sato, and R. Ruedy, Radiative forcing and climate response, J. Geophys. Res., 102, 6831-6864, 1997.

Haywood, J. M., P. N. Francis, M. D. Glew, and J. P. Taylor, Optical properties and direct radiative effect of Saharan dust: A case study of two Saharan outbreaks using data from the U. K. Met. Office C-130, J. Geophys. Res., 106, 18,417-18,430, 2001.

Haywood, J. M., et al., Radiative properties and direct radiative effect of Saharan dust measured by the C-130 aircraft during Saharan Dust Experiment (SHADE). 1: Solar spectrum, J. Geophys. Res., 108(D18), doi:10.1029/2002JD002687, in press, 2003.

Highwood, E. J., J. M. Haywood, M. Silverstone, S. M. Newman, and J. P. Taylor, Radiative properties and direct effect of Saharan dust measured by the C-130 aircraft during Saharan Dust Experiment (SHADE). 2: Terrestrial spectrum, J. Geophys. Res., 108(D18), doi:10.1029/ 2002JD002552, in press, 2003.

Holben, B. N., et al., AERONET-A federated instrument network and data archive for aerosol characterization, Remote Sens. Environ., 66, $1-16,1998$.

Holben, B. N., et al., An emerging ground-based aerosol climatology: Aerosol optical depth from AERONET, J. Geophys. Res., 106, 12,067-12,097, 2001.

Intergovernmental Panel on Climate Change (IPCC), Climate Change 2001: The Scientific Basis. Contribution of Working Group I to the Third Assessment Report of the Intergovernmental Panel on Climate Change, edited by J. T. Houghton et al., 881 pp., Cambridge Univ. Press, New York, 2001.

Jaenicke, R., and L. Schütz, Comprehensive study of physical and chemical properties of the surface aerosols in the Cape Verde Islands region, J. Geophys. Res., 83, 3585-3599, 1978.

Karyampudi, V. M., et al., Validation of the Saharan dust plume conceptual model using lidar, Meteosat and ECMWF data, Bull. Am. Meteorol Soc., 80, 1045-1075, 1999.

Kaufman, Y. J., D. Tanré, L. A. Remer, E. F. Vermote, A. Chu, and B. N. Holben, Operational remote sensing of tropospheric aerosol over land from EOS moderate-resolution imaging spectroradiometer, J. Geophys. Res., 102, 17,051-17,067, 1997.

Kaufman, Y. J., D. Tanré, O. Dubovik, A. Karnieli, and L. A. Remer, Absorption of sunlight by dust as inferred from satellite and groundbased remote sensing, Geophys. Res. Lett., 28, 1479-1482, 2001.

Kaufman, Y. J., D. Tanré, J.-F. Léon, and J. Pelon, Retrieval of profiles of fine and coarse aerosols using Lidar and radiometric space measurements, IEEE Trans. Geosci. Remote Sens., in press, 2003.

King, M. D., Y. J. Kaufman, W. P. Menzel, and D. Tanré, Remote sensing of cloud, aerosol, and water vapor properties from the Moderate-resolution Imaging Spectrometer (MODIS), IEEE Trans. Geosci. Remote Sens., 30, 2-27, 1992.

Léon, J.-F., P. Chazette, J. Pelon, F. Dulac, and H. Ramdriamiarisoa, Aerosol direct radiative impact over the INDOEX area based on passive and active remote sensing, J. Geophys. Res., 107(D19), 8006, doi:10.1029/ 2000JD000116, 2002.

Léon, J.-F., D. Tanre, J. Pelon, Y. J. Kaufman, J. M. Haywood, and B. Chatenet, Profiling of a Saharan dust outbreak based on a synergy between active and passive remote sensing, J. Geophys. Res., 108(D18), doi:10.1029/2002JD002774, in press, 2003.

Levy, R. C., L. A. Remer, D. Tanré, Y. J. Kaufman, C. Ichoku, B. N. Holben, J. Livingston, P. Russell, and H. Maring, Evaluation of the Moderate-Resolution Imaging Spectroradiometer (MODIS) retrievals of dust aerosol over the ocean during PRIDE, J. Geophys. Res., 108, doi:10.1029/2002JD002460, in press, 2003.

Martins, J. V., D. Tanré, L. Remer, Y. Kaufman, S. Mattoo, and R. Levy, MODIS Cloud screening for remote sensing of aerosols over oceans using spatial variability, Geophys. Res. Lett., 29(12), 8009, doi:10.1029/2001GL013252, 2002.

Myhre, G., A. Grini, J. M. Haywood, F. Stordal, B. Chatenet, D. Tanre, J. Sundet, and I. Isaksen, Modeling the radiative impact of mineral dust during the Saharan Dust Experiment (SHADE) campaign, J. Geophys. Res., 108(D18), doi:10.1029/2002JD002566, in press, 2003.

Nakajima, T., G. Tonna, R. Rao, Y. Kaufman, and B. Holben, Use of sky brightness measurements from ground for remote sensing of particulate polydispersions, Appl. Opt., 35, 2672-2686, 1996.

Pelon, J., P. H. Flamant, and M. Meissonnier, The French airborne backscatter Lidar LEANDRE-1: Conception and operation, paper presented at 15 th International Laser Radar Conference, Int. Coord. Group on Laser Atmos. Stud., Tomsk, 1990.
Penner, J., et al., Aerosols: Their direct and indirect effects, in Climate Change 2001: The Scientific Basis, Contribution of Working Group I to the Third Assessment Report of the Intergovernmental Panel on Climate Change, edited by J. T. Houghton et al., pp. 289-348, Cambridge Univ. Press, New York, 2001.

Prospero, J. M., and T. N. Carlson, Vertical and areal distribution of Saharan dust over the western equatorial north Atlantic Ocean, J. Geophys. Res., 77, 5255-5265, 1972.

Ramanathan, V., et al., The Indian Ocean Experiment: An integrated analysis of the climate forcing and effects of the great Indo-Asia haze, J. Geophys. Res., 106, 28,371-28,398, 2001.

Ramaswamy, V., O. Boucher, J. Haigh, D. Hauglustaine, J. M. Haywood, G. Myhre, T. Nakajima, G. Y. Shi, and S. Solomon, Radiative forcing of climate change, in Climate Change 2001: The Scientific Basis, Contribution of Working Group I to the Third Assessment Report of the Intergovernmental Panel on Climate Change, edited by J. T. Houghton et al., pp. 349-416, Cambridge Univ. Press, New York, 2001.

Remer, L. A., et al., Validation of MODIS aerosol retrieval over ocean, Geophys. Res. Lett., 29(12), 8008, doi:10.1029/2001GL013204, 2002.

Ryall, D. B. and R. H. Maryon, Validation of the UK Met Office's NAME model against the ETEX dataset, Atmos. Environ., 32, 4265-4276, 1998.

Ryall, D. B., R. G. Derwent, A. J. Manning, A. L. Redington, J. Corden, W. Millington, P. G. Simmonds, S. O. Doherty, N. Carslaw, and G. W. Fuller, The origin of high particulate concentrations over the United Kingdom, March 2000, Atmos. Environ., 36, 1363-1378, 2002.

Smirnov, A., B. N. Holben, T. F. Eck, O. Dubovik, and I. Slutsker, Cloud screening and quality control algorithms for the AERONET data base, Remote Sens. Environ., 73, 337-349, 2000.

Sokolik, I. N., O. B. Toon, and R. W. Bergstrom, Modeling of the radiative characteristics of airborne mineral aerosols at IR wavelengths, J. Geophys. Res., 103, 8813-8826, 1998.

Sokolik, I. N., D. M. Winker, G. Bergametti, D. A. Gillette, G. Carmichael, Y. J. Kaufman, L. Gomes, L. Schuetz, and J. E. Penner, Introduction to special section: Outstanding problems in quantifying the radiative impacts of mineral dust, J. Geophys. Res., 106, 18,015-18,027, 2001.

Tanré, D., Y. J. Kaufman, M. Herman, and S. Mattoo, Remote sensing of aerosol properties over oceans using the MODIS/EOS spectral radiances., J. Geophys. Res., 102, 16,971-16,988, 1997.

Tanré, D., Y. J. Kaufman, B. N. Holben, B. Chatenet, A. Karnieli, F. Lavenu, L. Blarel, O. Dubovik, L. A. Remer, and A. Smirnov, Climatology of dust aerosol size distribution and optical properties derived from remotely sensed data in the solar spectrum, J. Geophys. Res., 106, 18,205-18,218, 2001.

Tegen, I., A. A. Lacis, and I. Fung, The influence on climate forcing of mineral aerosols from disturbed soils, Nature, 380, 419-422, 1996.

Volz, F. E., Infrared optical constants of ammonium sulphate, Sahara dust, volcanic pumice and fly ash, Appl. Opt., 12, 564-567, 1973.

Wielicki, B. A., et al., Clouds and the Earth's radiant energy system (CERES): An Earth observing system experiment, Bull. Am. Meteorol. Soc., 77, 853-868, 1996.

Winker, D., J. Pelon, and M. P. McCormick, The CALIPSO mission: Aerosol and cloud observations from space, paper presented at 21st International Lidar Radar Conference, Int. Coord. Group on Laser Atmos. Stud., Québec, 8-10 July 2002.

World Meteorological Organization (WMO), Radiation commission of IAMAP meeting of experts on aerosol and their climatic effects, Rep. WCP55, Williamsburg, Va., 28-30 March 1983.

B. Chatenet, Laboratoire Inter-Universitaire des Systèmes Atmosphériques, CNRS, Université Paris 7 \& 12, 61, avenue du Général de Gaulle, F-94010 Créteil, France. (chatenet@lisa.univ-paris12.fr)

P. Formenti, Centre of Geophysics of Evora, Universidade de Évora, Rua R. Ramalho, 59 P 7000 Evora, Portugal. (formenti@lisa.univ-paris12.fr)

P. Francis and J. Haywood, Met Office, Y46 Building, DERA, Fanborough, Hants GU14 0LX, UK. (pnfrancis@metoffice.com; jmhaywood@ metoffice.com)

P. Goloub, J. F. Léon, and D. Tanré, Laboratoire d'Optique Atmosphérique, CNRS, Université des Sciences et Technologies de Lille 1, F-59655, Villeneuve-d'Ascq CEDEX, France. (leon@loa.univ-lille1.fr; goloub@ loa.univ-lille1.fr; tanre@loa.univ-lille1.fr.)

E. Highwood, Department of Meteorology, University of Reading, PO Box 243, Reading RG6 6BB, UK. (e.j.highwood@reading.ac.uk)

G. Myhre, Department of Geophysics, University of Oslo, PO Box 1022, Blindern, N-0215 Oslo, Norway. (gunnar.myhre@geofysikk.uio.no)

J. Pelon, Service d'Aéronomie, Institut Pierre Simon Laplace, CNRS, Université Pierre et Marie Curie, F-75252 Paris, France. (jpe@sirocco.aero. jussieu.fr) 